\title{
Project Based Learning to Enhance Students' Science Process Skills in Science Learning
}

\author{
Halimatussa' diah ${ }^{1}$, H. Sitompul², R. Mursid ${ }^{3}$ \\ Postgraduate Educational Technology Study Program, Universitas Negeri Medan ${ }^{1,2,3}$ \\ halimahpanjaitan43@gmail.com
}

\begin{abstract}
Learning is a process of student interaction with teachers and learning resources in a learning environment. This study aims to determine the effect of applying project based learning models on science process skills on the material structure of animal and plant cells. The design used in this study is a posttest-only control design with a quasi-experimental method. The research sample consisted of 55 students and the result shows that the implementation of Project Based Learning model is better than conventional learning models. This can be seen from the t-test calculation of science process skills showing a significant result of $\mathrm{t}$ count $0.003<0.05$, then $\mathrm{Ha}$ is accepted and Ho is rejected. From the analysis of average completeness score indicators of the experiment class science process skills reached 2.50 with good criteria while the science process skills of students in the control class reached 1.68 in sufficient criteria meaning that the science process skills of the experiment class students were higher than the science process skills of the control class. It can be concluded that the Project Based Learning model influences the Science Process Skills on the material structure of animal cells and plant cells.
\end{abstract}

Keywords: project based learning model, science process skills

\section{Introduction}

The purpose of Education is to develop the students' potential to become human beings who have faith, devote to God Almighty, good character, healthy, knowledgeable, capable, creative, independent, interactive, inspirational, fun, challenging, actively participate, and provide space which is sufficient for initiative, creativity, and independence in accordance with talents, interests and physical development, and to be democratic and responsible citizens. Science learning seeks to increase students' interest in developing knowledge, skills and abilities to think about the whole nature that is full of endless secrets. Based on Ministry of Education Regulation No. 20 of 2016, Competency Standards for Junior High School Education Graduates are students who can search and apply information that comes from the environment and other sources logically, critically and creatively and students can demonstrate the ability to analyze and solve problems in daily life.

The 21st century is an age of unlimited knowledge, where information and technology are increasingly developing. The 21 st century learning paradigm emphasizes the students' ability to find 
out from various sources, formulate problems, think analytically and cooperate and collaborate in solving problems [1]. In this 21 st century the ability to learn, think creatively, make decisions, and solve problems is very necessary in getting a job, so science education should be able to help students to develop understanding and thinking habits to ensure their survival [2].

Science is the knowledge gained through observation, data collection by experimentation and deduction to produce an explanation of a phenomenon that can be trusted. The application of a scientific approach in learning involves a variety of science process skills such as observing, classifying, measuring, hypothesizing, explaining, and concluding. Science learning places more emphasis on the application of science process skills. Aspects of the scientific approach are integrated with the science process skills approach and scientific method. Two things that are important in learning science are helping students to gain a deep understanding of the material presented and helping them build problem-solving skills. Problem solving skills are part of thinking skills. Science Process skills need to be developed through direct experiences as learning experiences. Through direct experience, a person can better appreciate the process or activity that is being carried out. The science process skills approach is a learning process that is designed so that students can find facts, construct concepts and theories with students' own intellectual skills and scientific attitudes.

The fact that can be seen at this time there are many students who are not active enough in learning, information acquisition is only one way, teachers provide knowledge and students receive knowledge without reprocessing it. This raises a problem in learning that is the potential of students are not sufficiently explored, aspects of learning skills do not develop which causes student achievement to be less improved. Another obstacle is the unavailability of learning facilities to support the learning process so that students do not understand the learning material let alone abstract concepts. Lack of problem solving skills in student and understanding the concepts of science being studied requires improvement. In studying science students are more interested in conducting experiments or observations in the surrounding environment. The application of experimental learning will help students to understand the concepts. Students' concepts understanding can be seen if students are able to express verbally, in writing, and applications in their daily lives. Thus, students have the ability to explain, mention, give examples, and apply concepts related to the subject.

The learning process that can improve students' mastery of concepts and problem solving skill is a learning process that can actively involve students in building their knowledge through daily experiences, previous experiences as well as current learning. Science learning should be able to provide direct experience for students so that it adds to the ability of nature to construct, understand and apply concepts holistically, meaningfully, authentically and applicatively for the purpose of solving problems. Based on the importance of problem solving skills, it is necessary to study how to design learning models that can be applied to improve problem-solving skills in learning science at the middle school. One learning model that is expected to improve problem-solving skills is the PjBL learning model that is expected to accommodate active, innovative, creative, effective and fun learning.

Project-based learning (PjBL) is one way to develop the skills demanded in 21 st century education. PjBL can train students to change the nature of learning by discovering basic concepts through the expansion of information and communication technology that will be essential for success in facing life in the future (Ledward in Ahira, 2011). Project Based Learning in general has 
a step guide: 1) start with the essential question, 2) design a plan for the project, 3) create a schedule, 4) monitor the sudents and the progress of the project, 5) assess the outcome, and 6) evaluate the experience [3]. The six steps are carried out by students with the help of teacher as the facilitator. Project Based Learning can make students experience a meaningful learning process, students build their knowledge in the context of their own experiences and with direct learning experience that can support skills development [4]. Through direct experience a person can better appreciate the process or activity being carried out [5]. Project-based learning focuses on questions or problems that drive through concepts and principles. Project-based learning also engages students in constructive investigations. This investigation is in the form of design, decision-making, problem discovery, problem solving, discovery or the model development process. In project-based learning, these activities must be included in the transformation and construction of knowledge on the part of students. This learning encourages students to gain a learning experience to a significant degree. Project-based learning places more emphasis on autonomy, choice, uncomplicated work time, and student responsibility. The targets for project-based learning are the products produced.

The project-based learning model can empower students to develop creativity through projectbased problem solving activities. Abidin [6] stated that the project-based learning model is considered as one of the excellent learning models in developing various basic skills that students must have such as decision making skills, creative abilities and problem solving skills. The same thing also expressed by Hwang [7] that creativity is an ability that can be developed through the problem solving process. According to Aktamis \& Omer [8] someone who is creative will be able to find new problem solving method to solve problems they encountered in daily life. In addition, creative people will also be more sensitive to problems. In addition in carrying out learning activities based on problem solving, a person also needs certain abilities such as observing, inferring, experiment or referred to as science process skills.

Science process skills are scientific thinking skills that are useful for solving problems and formulating results [9]. Science process skills are all scientific skills that can be used to find a concept or principle or theory to develop an existing concept or to refute an invention. Science process skills are typical intellectual skills that are used by all scientists and can be used to understand any phenomenon, where these skills are needed to acquire, develop and apply concepts, legal principles and scientific theories. Project-based learning can familiarize students with scientific methods that directly provide opportunities for students to develop their science process skills [10]. In addition, according to Siwa, Muderawan \& Tika [11], in project-based learning a person will learn much better because he is actively involved in the learning process, think about what is learned and then applying what has been learned in real situations [12].

\section{Research methods}

This research was conducted in VII class of MTsN 2 Medan. This research is a quasiexperimental study. The research designed with posttest-only control design. The experiment class (class 7 plus 1) consisted of 28 students who were treated with the Project Based Learning model, while the control class consisted of 27 students (classes 7 plus 2) were treated learning using the team discussion method. The techniques used for data collection in this study were in the form of 
non-tests (observation sheets and performance) and tests (posttest). Data collection in this study uses observation sheets as data on science process skills, with Participant observation and structured observation sheets and Posttest to compare differences in students' process skills in the two classes.

\section{Results and Discussion}

The Science Process Skills (SPS) of the students studied in this study include several indicators: 1) asking questions; 2) hypothesize; 3) plan an experiment; 4) observation 5) interpret / interpret; 6) communicate. This study uses two classes, the experiment class which is treated using a project-based learning model (PPA) and the control class without treatment. The results were obtained from SPS observation sheets during learning, and posttest at the end of learning. The results of the study are presented as follows.

Table 1. Observation Result Sheet Percentage completeness (\%) Experiment Class and Control Class

\begin{tabular}{llcc}
\hline No & Aspect & \multicolumn{2}{c}{ Completeness Percentage } \\
\cline { 3 - 4 } & & $\begin{array}{c}\text { Experiment } \\
\text { Class }\end{array}$ & Control Class \\
\hline 1 & Ask question & $65 \%$ & $45 \%$ \\
2 & Hypothesize & $65 \%$ & $40 \%$ \\
3 & Plan an experiment & $60 \%$ & $35 \%$ \\
4 & Observation & $60 \%$ & $45 \%$ \\
5 & Interpret & $55 \%$ & $40 \%$ \\
6 & Communicate & $70 \%$ & $55 \%$ \\
\hline
\end{tabular}

In calculating the observation sheet this study uses a scale of 1 to 4 . There are differences in the average scores of the experiment class and the control class. As shown in table 2.

Table 2. Average score of observation classes in experiment and control classes

\begin{tabular}{clcl}
\hline No. & \multicolumn{1}{c}{ Class } & Average Score & Criteria \\
\hline 1. & Experiment Class & 2,50 & Good \\
2. & Control Class & 1,68 & Average \\
\hline
\end{tabular}

Performance evaluation is carried out to see the implementation of the project-based learning model in the experimental class. This performance evaluation consisted of three stages including planning stage, implementation and product results. As shown in table 3, the final test (Posttest) was carried out as an evaluation of the achievement of the material structure from animal cells and plant cells with indicators of science process skills. The posttest results from experiment and control class can be seen in Table 4 and Figure 1. Based on the data obtained through the observation sheet of the science process skills during three sessions, the posttest shows that there are differences between the experiment classes using the project-based learning model and the control class. The average 
total score of the observation sheet was obtained that in the experimental class the average score was 2.50 that had good criteria while in the control class the average score of 1.68 had sufficient criteria. This shows that the experimental class using the project-based learning model, its science process skills are better than the control class that uses conventional learning.

Table 3 Results of process and product performance evaluations

\begin{tabular}{ccccccc}
\hline \multirow{2}{*}{ No } & \multirow{2}{*}{ Group } & \multicolumn{2}{c}{ Project based Learning Model Assessment Phase } & \multirow{2}{*}{ Total } & Cretieria \\
\hline 1 & Group 1 & 11 & 11 & 12 & 94 & Very good \\
2 & Group 2 & 10 & 11 & 9 & 83 & Good \\
3 & Group 3 & 10 & 9 & 9 & 58 & Average \\
4 & Group 4 & 11 & 11 & 11 & 92 & Very good \\
5 & Group 5 & 9 & 9 & 9 & 75 & Good \\
\hline
\end{tabular}

Table 4 Completeness percentage of each science process skills indicator in the experiment and control class

\begin{tabular}{|c|c|c|c|}
\hline \multirow[t]{2}{*}{ No } & \multirow[t]{2}{*}{ Aspect } & \multicolumn{2}{|c|}{ Completeness Percentage } \\
\hline & & Experiment Class & Control Class \\
\hline 1 & Ask question & $85 \%$ & $75 \%$ \\
\hline 2 & Hypothesize & $80 \%$ & $65 \%$ \\
\hline 3 & Plan an experiment & $75 \%$ & $65 \%$ \\
\hline 4 & Observation & $90 \%$ & $80 \%$ \\
\hline 5 & Interpret & $80 \%$ & $60 \%$ \\
\hline 6 & Communicate & $90 \%$ & $75 \%$ \\
\hline
\end{tabular}

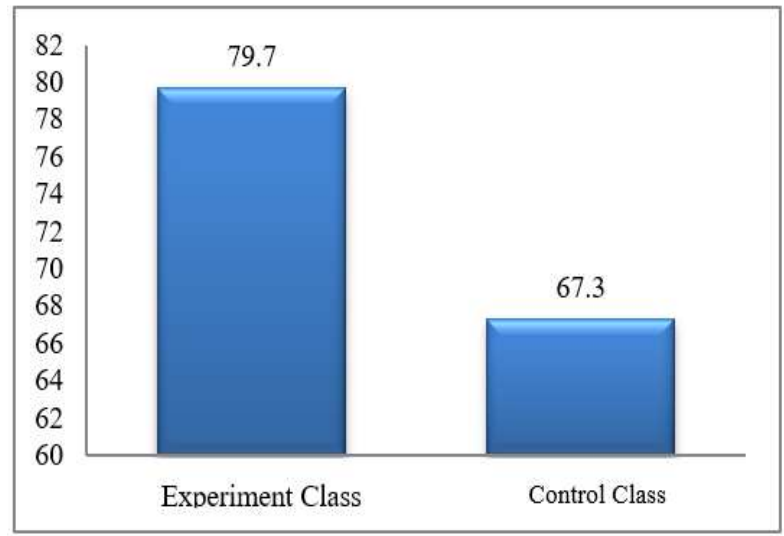

Fig 1. Diagram of posttest experiment and control grade average values 
In Figure 1 it can be seen that the highest indicator of science process skills in the experiment and the control class is in the communication and interpretation skills indicator that is $70 \%$ and $55 \%$. Both in experiment and control class observation skills get a percentage of 90 with a very good category. Observing indicators are basic skills for other process skills that lead students to find real experiences in the form of conceptual understanding. In accordance with what was stated by Katimi \& Ayani [13], that students who make observations will be easier to capture what they see compared to memorizing a material. Observing skills are skills that are easier to emerge than the nine other indicators [14]. It appears that students discuss with each other in their groups about the observations they get, so that observations are obtained to the maximum. Observing indicators produce high performance scores. This has a positive impact on improving the indicators of classifying students. In accordance with what was stated [15] that the achievements of each indicator of science process skills are related to each other. The results of the achievement value of high observing skills affect the high classification skills. This is due to students who make careful observations resulting in increased classifying skills [16].

In addition to using the observation sheet this study also conducted a performance evaluation in the experiment class, this assessment was carried out in the second session, after students present the results of their project, the observers were given a performance evaluation sheet. In this experiment class students are divided into five groups, each group has its own identities, students start from the application of project-based learning models that have been instructed to make the plant and animal cell project. Performance sheet rubric assesses starting from the planning stage, the implementation stage and the results stage. Based on the assessment of the five groups, the group that obtained the highest score of group one has a value of 94 and the value of group four has a value of 92 because the products they produce are cell organelles derived from formed plasticine, used balls and used cardboard and also the appearance and suitability of the product with project objectives. Unlike the case with other groups, namely group two with a value of 83 and group four with a value of 75, they do not completely use used plastic material but they add flannel cloth and pipette. The third group with a value of 58 because the specified appearance and materials are incomplete and not in accordance with the expected project goals.

The benefits of learning done by making this project is students will easily understand the concept of learning cells that are abstract and they are more useful learning material. Based on the results of the process and product performance evaluation, it can be seen that the continuity of the use of the project-based learning model in the experimental class has very good criteria and is quite good because it is seen based on the assessment starting from the planning, implementation and results with a total value of $\geq 58$. It means that the project-based learning model can be used in learning and teaching activities in the classroom. This is supported by research which states that during work on projects, students are required to play an active role in various activities. Students can directly plan activities, solve problems and communicate the results of activities or products. Students gain a variety of learning experiences and the development of process skills.

Evaluation of learning achievement by using science process skills by means of posttest in the experimental class and control class with the results of the average value of the experiment class 79.7 and the control class average value of 67.3. This shows that in the experiment class student completeness in learning is higher than the control class. According to (Schneider, 2005; Musa et al, 2011) this happens because project-based learning teaches students to be creative, innovative, sharpen skills in making projects, and can improve student performance during learning. 


\section{Conclusions}

The application of project-based learning models has a significant effect on science process skills. The results of the observation showed the average score of the science process skills of the experiment class was higher at 2.50 with good criteria while the control class was 1.68 with sufficient criteria. The science process skills with the highest scores are seen in the observation and communication indicators that are $90 \%$. In addition, the results of the posttest mean score of the experiment class were 79.7 and the control class averaged 67.3. Suggestions in applying projectbased learning model can be applied by the teacher to find out the students' science process skills ability, but in preparation it takes a lot of time so that the learning can work well.

\section{References}

[1] Kemdikbud. Kurikulum 2013: Pergeseran Paradigma Belajar Abad 21. http://litbang.kemdikbud.go.id/index.php/indexberita-kurikulum/243-kurikulum-2013pergeseran-paradigma-belajar-abad-21. diakses 01 November 2019. (2013)

[2] Salpeter. 21st Century Skills: Have Student Ready (http://dca1to1.pbworks.com) diakses 5 November 2019. (2001)

[3] Harun, Y. Project Based Learning Handbook: Educating the Millennial Learner. Malaysia: Educational Technology Division-Ministry of Education. (2006)

[4] Wena, M. Strategi Pembelajaran Inovatif Kontemporer. Jakarta: Bumi Aksara. (2009)

[5] Rustaman, N. Strategi Belajar Mengajar Biologi. Bandung: JICA-UPI. (2005)

[6] Abidin, Y. Desain sistem pembelajaran dalam konteks Kurikulum 2013. Bandung: PT. Refika Aditama. (2014)

[7] Hwang W. Y., Nian-Shing C., Jian-Jie D., YiLun Y. Multiple representation skills and creativity effects on mathematical problem solving using a multimedia whiteboard system. Educational Technology \& Society, 10 (2), 191-212. (2007)

[8] Aktamis, H. \& Omer E. The Effect of scientific process skills education on students' scientific creativity, science attitudes and cademic achievements. AsiaPacific Forum on Science Learning and Teaching, Volume 9, Issue 1, Article 4, p.1. (2008)

[9] Ozgelen, S. Students' science process skills within a cognitive domain framework. eurasia Journal of Mathematics, Science \& Technology Education, 8(4), 283-292. (2012)

[10] Hayati, M. N., Kasmadi I. S., Siti S. M. Pengembangan pembelajaran IPA SMK dengan model kontekstual berbasi proyek. Innovative Journal of Curriculum and Educational Technology, 2 (1), $2252-7125$. (2013)

[11] Siwa, I. B., I.W. Muderawan, \& I. N. Tika. Pengaruh Pembelajaran Berbasis Proyek dalam Pembelajaran Kimia Terhadap Keterampilan Proses Sains Ditinjau dari Gaya Kognitif Siswa. e-Journal Program Pascasarjana Universitas Pendidikan Ganesha Volume 3 Tahun 2013. 
Singaraja: Program Studi Pendidikan IPA, Program Pascasarjana Universitas Pendidikan Ganesha. (2013)

[12] Nasir, M., Fakhrunnisa, R., \& Nastiti, L. R. The Implementation of Project-based Learning and Guided Inquiry to Improve Science Process Skills and Student Cognitive Learning Outcomes, 14(5), 229-238. (2019)

[13] Kartimi, Yulia. Ria., \& Ayani. Penerapan Pendekatan Keterampilan Proses dalam Pengajaran Biologi untuk Mengetahui Hasil Belajar Siswa pada Pokok Bahasan Ekosistem Kelas VII di SMPN 1 Talun. Jurnal Scientiae Educatia, 2 (1), 73-85. (2013)

[14] Zeidan, A. Hafez \& Jayosi, M. Rashed. Science Process Skills and Attitudes towards Science among Palestinian Secondary School Students. World Journal of Education, 5 (1), 13-24. (2015)

[15] Wahyuni, S., \& Suana, W. Jurnal Pendidikan IPA Indonesia Developing Science Process Skills and Problem- Solving Abilities Based on Outdoor Learning in Junior, 6(1), 165-169. https://doi.org/10.15294/jpii.v6i1.6849. (2017)

[16] Maradona. Analisis Keterampilan Proses Sains Siswa Kelas XI IPA SMA ISLAM Samarinda Pada Pokok Bahsan Hidrolisis Melalui Metode Eksperimen. Prosiding SeminarNasional Kimia 2013, (hal. 62-70). (2013)

[17] Hernawati, D. Integration of Project Activity to Enhance the Scientific Process Skill and SelfEfficacy in Zoology of Vertebrate Teaching and Learning, 14(6), 2475-2485. (2018)

[18] Musa, F., Mufti, N., Latiff, R. A., \& Amin, M. M. Project-based Learning: Promoting Meaningful Language Learning for Workplace Skills, 18, 187-195. https://doi.org/10.1016/j.sbspro.2011.05.027. (2011)

[19] Schneider, D.K. Project Based Learning. (Online). http://edutech wikiunige.ch/en/Project_Based_Le arning. Diakses 01 November 2019. (2005) 